\title{
LABORATORY AND FIELD EFFICACY OF SOME NATURAL AND CHEMICAL FORMULATION ON Aphis crassivora (KOCH) (HOMOPTERA : APHIDIDAE) AND ITS NATURAL ENEMIES \\ Ragab, M. E. ${ }^{1}$ N N. F. Abdel-Baky'; S. Abd-Rabou ${ }^{2}$ and Dina F. Elashram ${ }^{2}$ \\ 1- Dept. Economic Entomology, Fac. Agric., Mansoura Unvi. \\ 2- Plant Protection Research Institute, ARC, Dokki, Giza
}

\begin{abstract}
The cowpea aphid, Aphis crassivora (Koch) ( Homoptera : Aphididae) one of the most important pests in Egypt. This work dealt with the laboratory and field tests of the effect of Biofly, Neemex and Sumithion compounds on the cowpea aphid and its parasitoids and predators. The laboratory tests indicated that the potency of Biofly, Neemex and Sumithion was varied tremendously due to compounds and also, data proved that at any of the compounds the higher the concentration, the higher was the rate of mortality and vice versa. The obtained results indicated that, when $A$. crassivora, the parasitoid Aphidus ervi Haliday (Hymenoptera:Aphididea), the predator, Chrysoperla carnea (Steph.) (Neuroptera: Chrysopidae) and Coccinella undecimpunctata L. (Coleoptera : Coccinellidae) were treated with Biofly, Neemex and Sumithion, the mortality percentages ranged from61.4-92.5, 59.7-89.7, and 89.5100\%.; 62.8-93.6, 61.2-91.9 and 91.8-100\%; 61.5-91.3 ,59.6-88.6 and $89.7-100 \%$ and $59.8-92.7,58.2-80.5$ and $87.1-100 \%$, respectively. In the filed tests the results observed, the two compounds Biofly and Neemex gave moderate effect against adults, nymphs of $A$. crassivora, $C$. undecimpunctata, $C$. carnea and A.ervi with percent reduction $68.1 \& 74.3 \%$ and $64.43 \& 71.87 \% ; 68.2 \& 78.66 \%$ and $68.70 \&$ $75.8 \% ; 59.1 \& 56.1 \%$ and $60.3 \& 58.2 \% ; 57.2 \& 63.8 \%$ and $58.3 \& 68.4 \%$ and $63.60 \& 65.1 \%$ and 66.8 and $60.4 \%$ after 15 days, in the first and second years, respectively. On the other hand, Sumithion gave high efficacy against all targets, adult, nymphs of $A$. craccivora, $C$. undecimpunctata , $C$. carnea and A.ervi with percent reduction 97.5 and $97.3 ; 96.8$ and $96.6 \% ; 94.6$ and $95.8 ; 96.7 \%$ and $95.6 \%$ and $97.6 \%$ and $98.7 \%$ after 15 days from application in the first and second years, respectively.
\end{abstract}

\section{INTRODUCTION}

The cowpea aphid, Aphis crassivora (Koch) ( Homoptera : Aphididae) are small insects which live in dense colonies on growing plants. They are on of the most widespread groups of pests in agricultural systems in Egypt. Plants in these production system may be affected directly or indirectly as a result of the cowpea aphid population. Direct effects come about through suction of feeding aphids, injection of active substances into the plant tissue, interference with the physiological performance of crops and the removal of amino-nitrogen from the plants. Indirect effects are caused by virus transmission, honeydew excretion and changes in the micro flora communities on plants surfaces which may influence crop physiology. Predators and parasitoids can be used for the biological control of aphid pests including, $A$. crassivora (Alavo and Accodji,2004). Parasitoids of $A$. crassivora found in Egypt play an important role in control of this pest that mainly exert a lot of damage to economic plant. The effect of Beauveria 
bassiana on A. craccivora was toxic (El-Hamady,1998). Dimetry and Schmidit (1992) and Abdel-Rahman et al. (2005) recorded toxic effect of Neemazal on larvae of A. craccivora and Aphis fabae Scopoli (Homoptera : Aphididae), respectively. Predators efficacy of Coccinella undecimpunctata L. ( Coleoptera : Coccinellidae) and Chrysoperla carnea (Steph.) (Neuroptera: Chrysopidae) on the immature stages of the main insect pests of different economic host plants was studied by Salem (2002). The effect of $B$. bassiana and Nemazal on the natural enemies of aphid pests, including $A$. craccivora was also studied by James, et al (1995), Haseeb and Murad (1997), Hermann et al. (1997), Sewify ( 1997), Vogt et al. (1997 and1998), Murphy et al.(1999), Mesquita and Lacey (2001), Biradar et al. (2002), Sharma and Kashyap (2002), Hamd et al. (2005), Kim et al. (2005), Naveen and Brar (2006), El-Wakeil et al. (2006) and Bidhan et al. ( 2008).

The aim of this work is to test the efficacy of some natural compound compared with a chemical compound on the cowpea aphid, A. crassivora and its natural enemies under both laboratory and field conditions.

\section{MATERIALS AND METHODS}

\section{Laboratory experiments:}

\subsection{Mass rearing of Aphis crassivora and its natural enemies:}

\subsubsection{Aphis crassivora:}

The broad bean, Vicia faba seeds were planted in plastic trays (25X $40 \times 15 \mathrm{~cm})$ or foam trays $(60 \times 25 \times 20 \mathrm{~cm}$ with 109 wholes) contained peat muss. The seeds were planted at $1-2 \mathrm{~cm}$ deep and followed with irrigation and fertilizers as required. When the first leaflet appeared after about one week from cultivation. Bean leaves were infested with $A$. craccivora which distributed over the new foliage of cultivated trays. Culturing of faba bean plants and artificial aphid infestation was a continuous process carried out at weekly intervals. The infested trays were followed until the population of $A$. craccivora increased. A. craccivora colonies were cultured under laboratory conditions $\left(23 \pm 2^{\circ} \mathrm{C}\right.$ and $60 \pm 5 \%$ R.H.).

\subsection{Aphidus ervi:}

Culture of $A$. ervi was started that emerged from the collected specimens from the field and the colony was reared on $A$. craccivora feeding potted broad bean, $V$. faba. The laboratory conditions were 25-27 Co and 6570 R.H.

\subsection{Chrysoperla carnea:}

C. carnea adults were collected from the field by insect sweeping net and brought to the laboratory. The collected adults feeding on yeast and honey and the colony was reared when larvae fed on frozen eggs of Sitotroga cerellela (Olivier). The laboratory conditions were 25-27 Co and 65-70 R.H.

\subsection{Coccinella undecimpunctata:}

Mass rearing of $C$. undecimpunctata was started that emerged from the collected specimens from the field and the colony was reared on $A$. craccivora feeding potted broad bean, $V$. faba. The laboratory conditions were 25-27 Co and 65-70 R.H. 


\section{2.Tested commercial formulation :}

Biofly, an entomopathogenic fungi $\left(3 X 10^{7} \mathrm{c}\right.$. fu $\left.1 \mathrm{ml}\right)$, containing the fungus Beauveria bassiana, used at a rate of $2 \mathrm{ml} /$ liter of water.

Neemex, a botanical extract containing $1 \%$ Azadirachtin a $(10 \mathrm{~g} /$ liter $)$ from the neem tree, Azadirachta indica (Meliaceae), applied at a rate of $2 \mathrm{ml} /$ liter of water.

Sumithion $50 \%$ EC a chemical pesticide was applied at a rate of $2 \mathrm{ml} /$ liter of water.

\section{3. Tested methods}

The laboratory experiments were carried out in the Laboratory of Plant Protection Research Institute, ARC, Dokki, Giza. The method of indirect exposure was used to evaluate the effect of the three compounds on the parasitoid (A. ervi), predators (C. carnea \& C. undecimpunctata) and prey throughout the present investigation. Five concentrations of Biofly, Neemex and Sumithion were used; twenty infested leaves of broad bean plants were dipped in each concentration for five seconds. Leaves were divided into five replicates. Five leaves were dipped in clean water as untreated check (control). The leaves were transferred to clean wide plastic dishes, which were then covered with muslin cloth held in position by rubber bands. The culture was maintained at room temperature about $25 \pm 1^{\circ} \mathrm{C}$ and $65 \pm 1 \%$ relative humidity. After 24 hours the alive predators, parasitoid and $A$. craccivora were counted.

\section{4. Statistical analysis}

In laboratory tests, the mortality percentages were calculated and corrected for natural mortalities by Abbott's formula (1925). The corrected percent mortalities were statistically computed according to Finney (1971) and plotted on probit analysis paper. The tested compounds were compared for their efficiency on the predators and parasitoid and prey according to their $\mathrm{LC}_{50}, \mathrm{LC}_{90}$ and slopes of the toxicity lines.

\section{Field experiments:}

The experiments were carried out to evaluate of the three compounds (Biofly, Neemex and Sumithion) on A. craccivora and its associated parasitoid and predators on broad beans were carried out at Qalubiya Governorate. When the numbers of $A$. craccivora and its predators and parasitoid were high during the two seasons, 2007 and 2008.

\subsection{The experiments comprised 3 compounds:}

Biofly, an entomopathogenic fungi ( $3 \times 10^{7}$ c.f.u. $/ 1 \mathrm{ml}$ ), containing the fungus Beauveria bassiana, used at a rate of $2 \mathrm{ml} /$ liter of water.

Neemex, a botanical extract containing $1 \%$ Azadirachtin A (10 g/liter) from the neem tree, Azadirachta indica (Meliaceae), applied at a rate of $2 \mathrm{ml} /$ liter of water.

Sumithion $50 \%$ EC a chemical pesticide was applied at a rate of $2 \mathrm{ml} /$ liter of water.

Each treatment conducted in $1 / 4$ Fadden. One quarter of Fadden was also used as an untreated check (control). Spraying was applied at the rate of per plant which was accomplished by the use of a Knapsack sprayer $\mathrm{Cp}-20$ of 20 liter capacity. Pre-spraying counts were made just before spraying. The post spraying counts were made after 3,7 and 15 days from 
application. Random samples of 20 leaves were picked up from each replicate. A total number of 60 infested leaves for each treatment thus examined. By means of a stereoscopic microscope insect was inspected.

\subsection{Statistical analysis}

The percent reduction of infestation was statistically calculated according to the equation of (Henderson and Tilton 1955).

Where:

$$
\% \text { mortality }=100[1 \text { - } \mathrm{Tb} \times \mathrm{Ca}
$$

$\mathrm{Ta}=$ Post treatment insect counts

$\mathrm{Cb}=$ Untreated insect count before treatment

$\mathrm{Tb}=$ Pretreatment counts

$\mathrm{Ca}=$ Untreated insect count after treatment.

\section{RESULTS}

\section{Laboratory Experiments:}

\subsection{On nymphs of Aphis crassivora:}

Data presented in Table (1) and graphically illustrated as toxicity lines in Fig. (1) showed the potency of Biofly, Neemex and Sumithion on nymphs of the cowpea aphid, A. crassivora under laboratory conditions. Tabulated data indicate that the potency of Biofly, Neemex and Sumithion was varied tremendously due to compounds. As a general trend, data proved that at any of the compounds the higher the concentration, the higher was the rate of mortality and vice versa. According to the obtained data (Table 1), different mortality percentages were recorded when $A$. crassivora were treated with Biofly, Neemex and Sumithion, the mortality percentages of $A$. crassivora nymphs ranged from $61.4-92.5,59.7-89.7$, and $89.5-100 \%$, respectively. When compare between the effects of Biofly, Neemex and Sumithion, it was found LC 50 were $(0.277,0.377$ and 0.085$)$, respectively (Fig. 1). On base of the LC90 values, it was found Biofly, Neemex and Sumithion, were (4.651, 8.925 and 0.54 ), respectively (Fig. 1). The slope of line is useful to known the homogeneity of stages of $A$. crassivora population, which reared under laboratory conditions to effect of different compounds. When the population of aphid insect is similar in homogeneity or the degree of resistant meaning the slope is big or increase in regression. Data in Fig. (1) showed that the slope of aphid population in Biofly, Neemex, and Sumithion, they gave (1.047, 0.931 and 1.596), respectively.

Table (1): Mortality percentages of Biofly, Neemex and Sumithion on nymphs of the cowpea aphid, Aphis crassivora under laboratory conditions .

\begin{tabular}{|c|c|c|c|c|c|}
\hline \multirow{2}{*}{ Compound } & \multicolumn{5}{|c|}{ Conc. (ml/L.W.) } \\
\cline { 2 - 6 } & $\mathbf{0 . 5}$ & $\mathbf{1}$ & $\mathbf{2}$ & $\mathbf{3}$ & $\mathbf{4}$ \\
\hline Biofly & 61.4 & 72.6 & 79.6 & 82.8 & 92.5 \\
\hline Neemex & 59.7 & 61.6 & 68.5 & 78.4 & 89.7 \\
\hline Sumithion & 89.5 & 94.8 & 98.9 & 100 & 100 \\
\hline
\end{tabular}




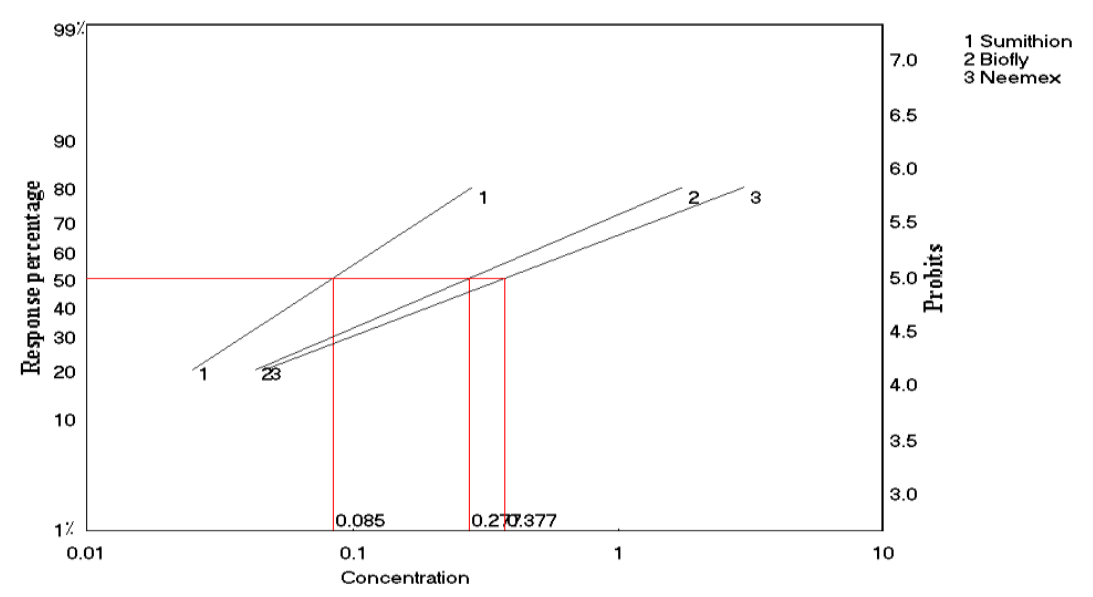

Fig. (1): LC values of Biofly, Neemex and Sumithion on nymphs of the cowpea aphid, Aphis crassivora (Koch) under laboratory conditions .

1.2. On emergency of aphid parasitoid, Aphidus ervi when Aphis crassivora treated by different compounds:

Data presented in Table (2) and graphically illustrated as toxicity lines in Fig. (2) showed the potency of Biofly, Neemex and Sumithion on emergence of $A$. ervi after treated $A$. crassivora with different compounds under laboratory conditions. Tabulated data indicate that the potency of Biofly, Neemex and Sumithion was varied tremendously due to compounds. As a general trend, data proved that at any of the compounds the higher the concentration, the higher was the rate of mortality and vice versa. According to the obtained data (Table 2), different mortality percentages on emergence of $A$. ervi were recorded when $A$. crassivora were treated with Biofly, Neemex and Sumithion, the mortality percentages ranged from 62.8-93.6, 61.2-91.9 and $91.8-100 \%$, respectively. When compare between the effects of Biofly, Neemex and Sumithion, it was found $\mathrm{LC}_{50}$ were $(0.264,0.325$ and 0.11$)$, respectively (Fig. 2). On base of the LC 90 values, it was found Biofly, Neemex and Sumithion, were $(3.936,7.007$ and 0.455$)$, respectively (Table, 4 \& Fig. 2). Data in Fig. (2) show that the slope of aphid population in Biofly, Neemex and Sumithion, they gave (1.092, 0.961 and 2.077), respectively.

Table (2): Mortality percentages of Biofly, Neemex and Sumithion on emergence of Aphidus ervi when treated the nymphs of the cowpea aphid, Aphis crassivora under laboratory conditions.

\begin{tabular}{|c|c|c|c|c|c|}
\hline \multirow{2}{*}{ Compound } & \multicolumn{5}{|c|}{ Conc. (ml/L.W.) } \\
\cline { 2 - 6 } & $\mathbf{0 . 5}$ & $\mathbf{1}$ & $\mathbf{2}$ & $\mathbf{3}$ & $\mathbf{4}$ \\
\hline Biofly & 62.8 & 73.9 & 81.6 & 84.5 & 93.6 \\
\hline Neemex & 61.2 & 65.8 & 71.8 & 79.6 & 91.9 \\
\hline Sumithion & 91.8 & 97.1 & 99.8 & 100 & 100 \\
\hline
\end{tabular}




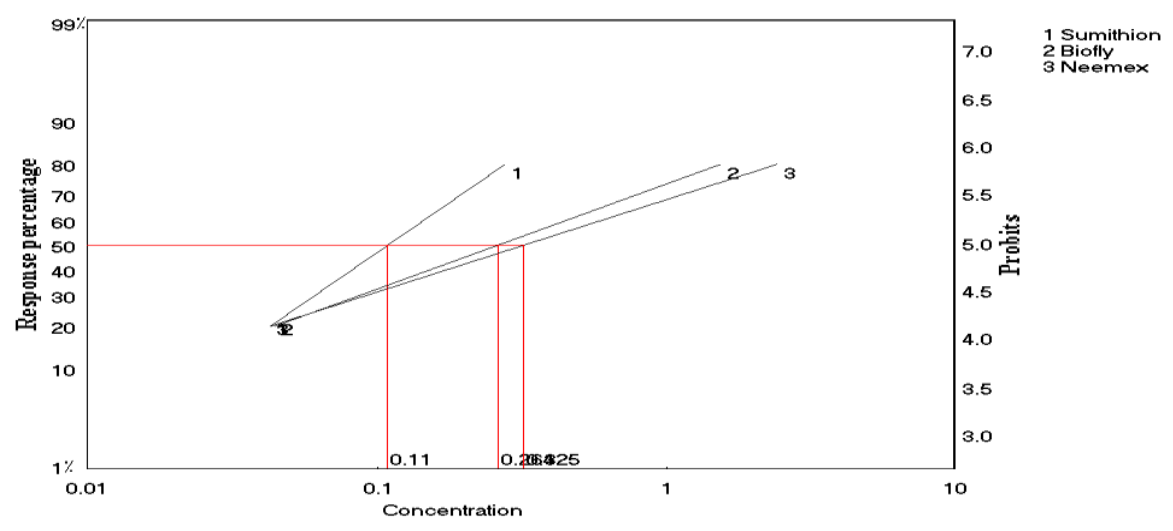

Fig.(2): LC values of Biofly, Neemex and Sumithion on emergence of Aphidus ervi when treated the nymphs of the cowpea aphid, Aphis crassivora (Koch) under laboratory conditions.

\section{3.On larvae of Chrysoperla carnea:}

Data presented in Table (3) and graphically illustrated as toxicity lines in Fig. (3) showed the potency of Biofly, Neemex and Sumithion on larvae of C. carnea with different compounds under laboratory conditions. Tabulated data indicate that the potency of Biofly, Neemex and Sumithion was varied tremendously due to compounds. As a general trend, data proved that at any of the compounds the higher the concentration, the higher was the rate of mortality and vice versa. According to the obtained data (Table 3), different mortality percentages on larvae of $C$. carnea treated with Biofly, Neemex and Sumithion, the mortality percentages ranged from 61.5-91.3, 59.6-88.6 and $89.7-100 \%$, respectively. When compare between the effects of Biofly, Neemex and Sumithion, it was found $\mathrm{LC}_{50}$ were $(0.279,0.32$ and 0.048$)$, respectively (Fig. 3). On base of the $\mathrm{LC}_{90}$ values, it was found Biofly, Neemex and Sumithion, were $(5.975,12.132$ and 0.546$)$, respectively (Fig. 3). Data in Figs (3) show that the slope of aphid population in Biofly, Neemex and Sumithion, they gave $(0.963,0.812$ and 1.21$)$, respectively.

Table (3): Mortality percentages of Biofly, Neemex and Sumithion on larvae of Chrysoperla carnea under laboratory conditions.

\begin{tabular}{|c|c|c|c|c|c|}
\hline \multirow{2}{*}{ Compound } & \multicolumn{5}{|c|}{ Conc. (mI/L.W.) } \\
\cline { 2 - 6 } & $\mathbf{0 . 5}$ & $\mathbf{1}$ & $\mathbf{2}$ & $\mathbf{3}$ & $\mathbf{4}$ \\
\hline Biofly & 61.5 & 70.4 & 75.4 & 81.6 & 91.3 \\
\hline Neemex & 59.6 & 63.9 & 69.9 & 73.7 & 88.6 \\
\hline Sumithion & 89.7 & 95.9 & 96.2 & 99.8 & 100 \\
\hline
\end{tabular}




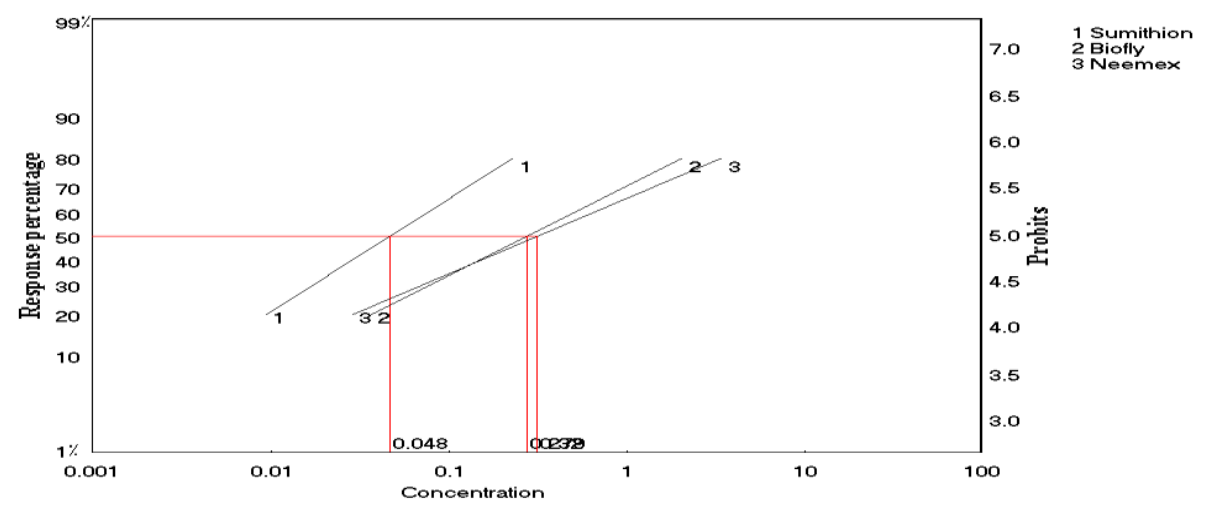

Fig.(3): LC values of Biofly, Neemex and Sumithion on larvae of Chrysoperla carnea under laboratory conditions

\subsubsection{On larvae of Coccinella undecimpunctata:}

Data presented in Table (4) and graphically illustrated as toxicity lines in Fig. (4) showed the potency of Neemex, Biofly and Sumithion on larvae of C. undecimpunctata with different compounds under laboratory conditions. Tabulated data indicate that the potency of Biofly, Neemex and Sumithion was varied tremendously due to compounds. As a general trend, data proved that at any of the compounds the higher the concentration, the higher was the rate of mortality and vice versa. According to the obtained data, different mortality percentages on larvae of $C$. undecimpunctata treated with Biofly, Neemex and Sumithion, the mortality percentages ranged from 59.8-92.7, 58.2-80.5 and $87.1-100 \%$, respectively. When compare between the effects of Biofly, Neemex and Sumithion, it was found LC 50 were $(0.355,0.356$ and 0.0005), respectively (Fig. 4). On base of the LC90 values, it was found Biofly, Neemex and Sumithion, were $(6.261,36.482$ and 1.371), respectively (Fig. 4). Data in Fig. (4) show that the slope of aphid population in Biofly, Neemex and Sumithion, they gave $(1.029,0.637$ and 0.372$)$, respectively.

\section{Field experiments:}

The experiments were carried out to evaluate of the three compounds (Biofly, Neemex, and Sumithion) on A. craccivora and associated parasitoid and predators on broad bean plants at Qalubiya Governorate. When the numbers of $A$. craccivora and its predators and parasitoid were high during the two successive seasons, 2007 and 2008.

Table (4): Mortality percentages of Biofly, Neemex and Sumithion on larvae of Coccinella undecimpunctata under laboratory conditions.

\begin{tabular}{|c|c|c|c|c|c|}
\hline \multirow{2}{*}{ Compound } & \multicolumn{5}{|c|}{ Conc. (mI/L.W.) } \\
\cline { 2 - 6 } & $\mathbf{0 . 5}$ & $\mathbf{1}$ & $\mathbf{2}$ & $\mathbf{3}$ & $\mathbf{4}$ \\
\hline Biofly & 59.8 & 65.8 & 72.8 & 79.6 & 92.7 \\
\hline Neemex & 58.2 & 58.2 & 61.7 & 71.9 & 80.5 \\
\hline Sumithion & 87.1 & 91.5 & 93.3 & 96.9 & 100 \\
\hline
\end{tabular}


Ragab,M. E. et al.

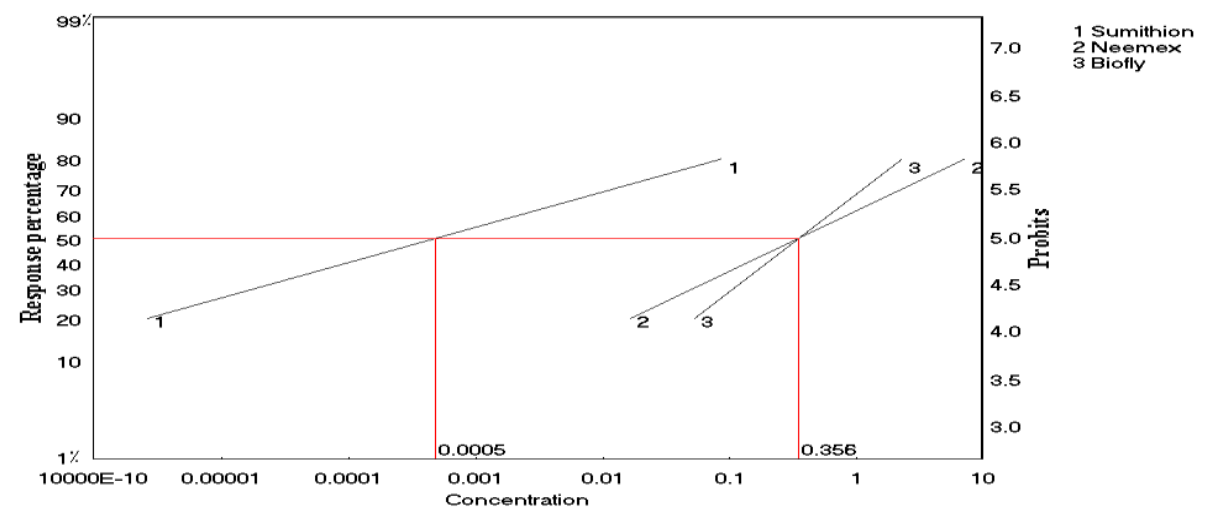

Fig. (4): LC values of Biofly, Neemex and Sumithion on larvae of Coccinella undecimpunctata under laboratory conditions

\subsection{The first season (2007):}

In the first season (2007), the average pre-spraying counts of adults and nymphs of $A$. craccivora were 40.1-45.7 and 79.6-84.3/leaf, respectively and the average numbers of $C$. undecimpunctata and $C$. carnea stages were 1.1-1.5 and 1.4-2.0/leaf,respectively and also the average number of the parasitoid, A. ervi was 4.8-5.9 (Table, 5). Results in Table (6) indicate that in first year (2007), the two compounds Biofly and Neemex gave moderate effect against adults and nymphs of $A$. crassivora, 74.3 and $68.1 \%$ reduction, respectively against adults after 15 days. Also, gave moderate effect against nymphs of $A$. crassivora, were 78.66 and $68.2 \%$ reduction, respectively after 15 days. They also showed moderate toxic effect against $C$. undecimpunctata stages (56.1 and 59.1\% reduction) also on C. carnea stages (63.8 and $57.2 \%$ reduction), respectively. While Biofly and Neemex were killed the parasitoid by 65.1 and $63.60 \%$, respectively. On the other hand, Sumithion gave high efficacy against all targets. Adult females and nymphs of $A$. craccivora were reduced by $97.5,96.8 \%$, respectively. Reduction in C. undecimpunctata and C. carnea stages of predators were 94.6 and $96.7 \%$ and on the parasitoid, $A$. ervi $(97.6 \%)$ after 15 days from application.

\subsubsection{The second season (2008):}

In the second season (2008), the average pre-spraying counts of adults and nymphs of $A$. craccivora were 35.9-40.5 and 77.4-79.2/leaf, respectively and the average numbers of $C$. undecimpunctata and $C$. carnea stages were 1.2-1.7 and 1.5-1.9/leaf,respectively and also the average number of the parasitoid, A. ervi was 5.3-6.2 (Table, 7). Results in Table (8) indicate that in second year (2008), the two compounds Biofly and Neemex gave moderate effect against adults and nymphs of $A$. crassivora, 75.8 and $68.6 \%$ reduction, respectively against adults after 15 days. Also, gave moderate effect against nymphs of $A$. crassivora, were 79.6 and $70.2 \%$ reduction, respectively after 15 days. They also showed moderate toxic effect against $C$. undecimpunctata stages (58.2 and $60.3 \%$ reduction) also on $C$. carnea stages (68.4 and $58.3 \%$ reduction), respectively. While Biofly and Neemex were killed 66.8 and $60.4 \%$ of parasitoid, respectively. 
J. Agric. Sci. Mansoura Univ., 34 (3), March, 2009

$5+6$

2163 
Ragab,M. E. et al.

$7+8$

2164 
On the other hand, Sumithion gave high efficacy against all targets. Adult females and nymphs of $A$. craccivora were reduced by 97.3 and $96.6 \%$, respectively. Reduction in $C$. undecimpunctata and $C$. carnea stages were 95.8 and $95.6 \%$ and on parasitoid (98.7\%).

\section{DISCUSSION}

The present work indicated that Biofly and Neemex gave moderate effect against adults and nymphs of $A$. crassivora. El-Hamady (1998) observed the effect of $B$. bassiana on $A$. craccivora was toxic, while Abdel-Rahman et al. (2005) and Dimetry and Schmidit (1992) recorded toxic effect of Neemazal on larvae of $A$. craccivora and A.faba, respectively. Azadirachtin indica was found to be the most effective compound against $A$. craccivora ranged, $80.47-89.6 \%$ mortality (Bidhan et al., 2008). The effect of the entomogenous fungus $B$. bassiana on $C$. septempunctata was highly susceptible (Haseeb and Murad,1997). El-Hamady (1998) said B. bassiana (Ld 50: $8.7 \times 108$ conidia/ $\mathrm{Kg} \mathrm{b}$. $\mathrm{w}$. equivalent to $29 \mathrm{ml}$ of the liquid preparation $/ \mathrm{kg}$. b. w.) was not toxic on C. undecimpunctata. But our results the Biofly ( $3 \times 10^{7}$ c.f.u. $/ 1 \mathrm{ml}$ ) has a moderate effect. Sewify ( 1997) stated that B. bassiana appeared a relative pathogenicity to the predators, $C$. undecimpunctat and C. carnea. Hermann et al. (1997) studied the effects of different NeemAzalformulations on larvae of the green lacewing C. carnea on 1st- and 2nd-instar larvae under laboratory conditions. They stated that, in the laboratory tests, larvae were exposed to a dried pesticide film on glass plates. High mortalities in laboratory experiments after a test period of 3-4 weeks led to the classification "harmful" for all formulations. NeemAzal-T/S at $0.3 \%$ was harmless to larvae of $C$. carnea in the field (Vogt et al. 1997). The same authors (1998) tested two formulations of azadirachtin, applied via residual contact in the laboratory at the highest recommended field concentrations $(0.3 \%$ NeemAzal-T/S and $0.15 \%$ Align) and the results indicated that, were highly toxic to first-instar larvae of the predator C. carnea. The dose of Neemark , $50 \mathrm{ml} /$ liter did not significantly affect on the population of $C$. undecimpunctata (Biradar et al., 2002). Sharma and Kashyap (2002) stated that Neemark (Azadirachta indica) at $0.3 \%$, was quite safe to $c$. septempunctata. In the present work also observed the percent reduction was 59.1 and $58.3 \%$ in the first and second years, respectively after 15 days from application. The mortality of the first instars of $C$. carnea was not affected by any of the azadirachtin enriched formulations (Naveen and Brar ,2006) . The results of tested Neem concentrations: 2, $1,0.5$ and $0.25 \% C$. carnea indicated that there were no serious side effects on efficiency of this predator (El-Wakeil et al.,2006). Results here recorded Neemex, a botanical extract containing $1 \%$ Azadirachtin gave moderate effect on C. carnea with percent reduction 57.2 and $58.3 \%$ during the two seasons under consideration, respectively. The parasitoid Aphidius sp. developed normally (approximately $90 \%$ adult emergence) when its aphid host was treated with fungi conidia 5 or 7 days after parasitization (Kim-Jeongjun et al. ,2005). Our results here observed the percent reduction of Biofly on $A$. ervi was 63.73 and $66.8 \%$ in the first and second years, respectively after 15 days from application. . 


\section{REFERENCES}

Abbot, W.S. (1925): A method of computing the effectiveness of an insecticide. J. Econ. Entomol.,18: 265-267.

Abdel-Rahman, G.A.; Belal,M.H.; Ibrahim, N.M. and Ali, E.A. (2005): Observations on toxic effects of some desert plant extracts on the cowpea aphid Aphis craccivora Koch. Egypt. J. Agric. Res., 83 ( 2): $609-621$.

Alavo, T. B. and Accodji, M. (2004): The entomopathogenic fungus Verticillium lecanii (Deuteromycetes, Moniliaceae). The proteins hydrophobins and the biological control of aphids (Homoptera, Aphididae): Literature review. Archives of Phytopathology and Plant Protection, 37 (3): 201- 204.

Bidhan C. D. , Pankoj, K. S. and Md Matiur, R. ( 2008) : Aphidicidal activity of some indigenous plant extracts against bean aphid Aphis craccivora Koch (Homoptera: Aphididae) . Journal of Pest Science , 81(3): 153159

Biradar, V.K. ; Shivpuje, P.R; Rawale, B.N. and Bansod, R.S. (2002): Effect of certain biopesticides on the population of lady bird beetle. Journal of Soils and Crops, 12 (1): 151-152.

Dimetry, N. Z. and Schmidt, G.H. (1992): Efficacy of Neem-Azal S and Margson-O against the bean aphid, Aphis faba Scop. Anz. Schadlingskunde, Pflanzenschutz, Umweltschutz, 65 (5): 75-79.

El-Hamady, S.E. (1998): Aphicidal efficiency of certain biorational with respect to their toxicity to some beneficial insects and mammals. Annals of Agricultural Science, Vol. 3: 1013- 1027.

El-Wakeil, N.E; Gaafar, N.M and Vidal, S (2006): Effects of the insecticide NeemAzal-T/S on the feeding, mortality and fecundity of the Hylobius abietis (L.) weevils. Revista Padurilor,121(4): 3-17.

Finney, D. J. (1971): Probit analysis, Cambridge University Press. $3^{\text {rd }}$ Edn., pp.333.

Hamd, E.E.A; El-Shafie, H.A.F and Basedow, T. ( 2005): The different effects of two preparations of neem (Azadirachta indica) and of Sumicidin Reg. on the aphid predator Hippodamia variegata (Goeze) (Coleoptera: Coccinellidae). Zeitschrift fur Pflanzenkrankheiten und Pflanzenschutz, 112 (6): 580-585.

Haseeb, M. and Murad, H. (1997): Pathogenicity of the entomogenous fungus Beauvaria bassiana (Bals.) vuill. to insect predators. International. Pest Control, 40 (2):50-51.

Henderson, C. F. and Tilton, E.W. (1955): Tests with acaricides against the brown wheat mite. J. Econ. Entomol., 48(2): 157-161.

Hermann, P.; Zebitz, C. P. W. and Kienzle, J. (1997): Effects of different NeemAzal-formulations on larvae of the green lacewing Chrysoperla carnea Steph. (Neuroptera, Chrysopidae) in laboratory and semi-field. Practice oriented results on use and production of neem ingredients and pheromones. Proceedings $5^{\text {th }}$ Workshop Wetzlar, Germany, 2225Jan-1996. 183-188. 
Jams, R.R.; Shaffer,B.T.; Croft, B. and Lighthart,B. (1995): Field evaluation of Beauveria bassiana its persistence and effects on the pea aphid and non-target coccinellid in alfalfa. Biocontrol science and technology, 5 (4):425-437.

Kim, J. J.; Kim K. C. and Roberts, D.w. (2005): Impact of the entomopathogenic fungus Verticillum lecanii on development of an aphid parasitoid, Aphidius colemani . Journal of Invertebrate Pathology, 88(3): 254-256.

Mesquita, A. L.M. and Lacey, L.A. (2001): Studied the intractions among the entomopathogenic fungus, Paecilomyces fumosoroseus ( Deuteromycotina : Hyphomycetes), the parasitoid, Aphelinus asychis (Hymenotera : Aphelinidae) and their aphid host. Biological Control, 22: 51-59.

Murphy, B.; Damm-Kattari, D.; Von, D.; Parrella, M. (1999): Interaction between fungal pathogens and natural enemies: implication for combined biocontrol of greenhouse pests. Bulletin OILB/ SROP. 22(1):181-184.

Naveen A. and Brar, D.S. (2006): Effects of different neem preparations in comparison to synthetic insecticides on the whitefly parasitoid Encarsia sophia (Hymenoptera: Aphelinidae) and the predator Chrysoperla carnea (Neuroptera: Chrysopidae) on cotton under laboratory conditions. Journal-of-Pest-Science, 9(4): 201-207.

Salem, F.A. (2002): Studies on some natural enemies of some aphid species at Kafr El-Sheikh region. Ph.D. Thesis, Fac. of Agric. Kafr El-Sheikh, Tanta Univ., 130pp.

Sewify, G.H. (1997): Occurrence and pathogenicity of entomopathogenic fungi in Egypt. $7^{\text {th }}$ Nat. Conf. of Pest \& Dis. Of Vegetables 7 Fruits in Egypt, pp: 380-392.

Sharma, D.C and Kashyap,N.P (2002). Impact of pesticidal spray on seasonal availability of natural predators and parasitoids in the tea ecosystem. Journal of Biological control, 16(1):31-35.

Vogt, H., Gonzalez, M., Adan, A., Smagghe, G. and Vinuela, E. (1998): Sideeffects of azadirachtin, via residual contact, on young larvae of the predator Chrysoperla carnea (Stephens) (Neuroptera, Chrysopidae). Boletin de Sanidad Vegetal, Plagas, 24(1): 67-78.

Vogt, H. ; Handel, U. and Vinuela, E. (1997): Field investigations on the efficacy of NeemAzal-T/S against Dysaphis plantaginea (Passerini) (Homoptera: Aphididae) and its effects on larvae of Chrysoperla carnea Stephens (Neuroptera: Chrysopidae). Practice oriented results on use and production of neem ingredients and pheromones. Proceedings-5thWorkshop-Wetzlar,-Germany,-22-25-Jan-1996. 105-114. 
Ragab,M. E. et al.

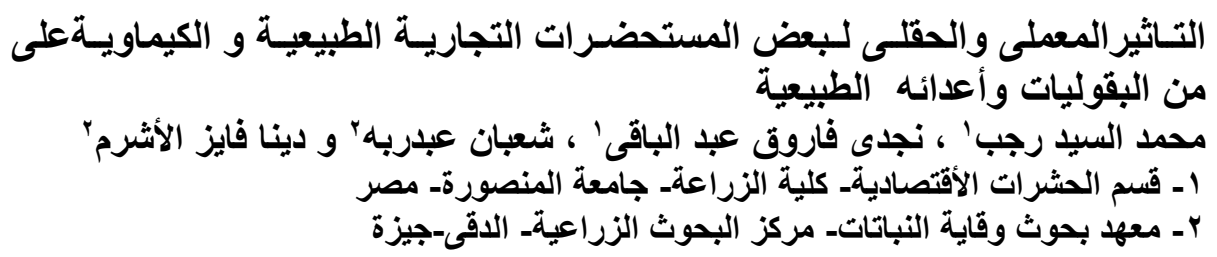

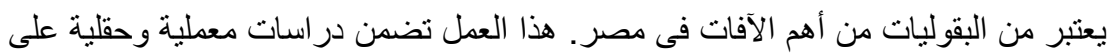

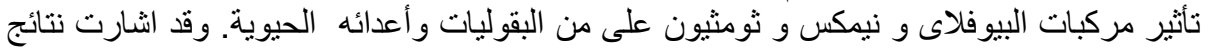

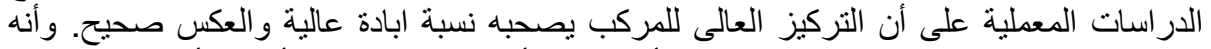

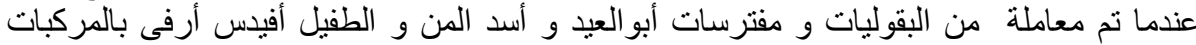

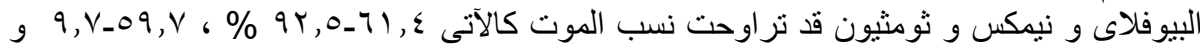

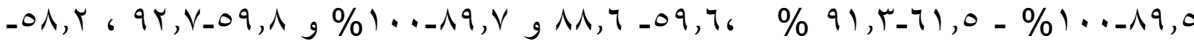

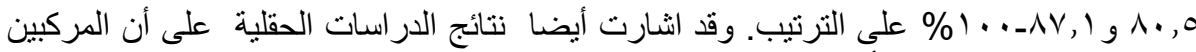

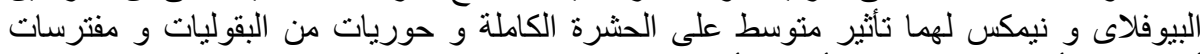

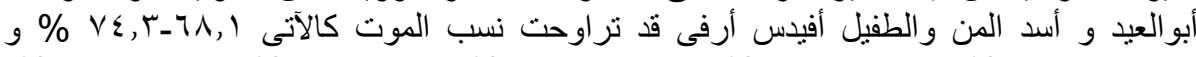

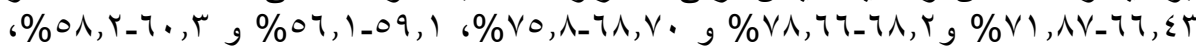

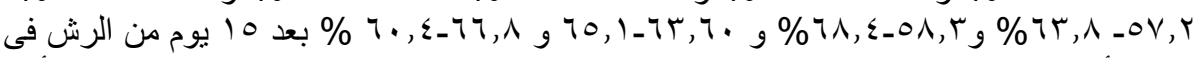

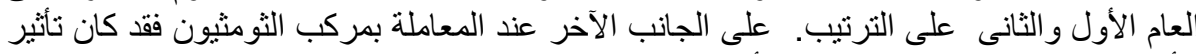

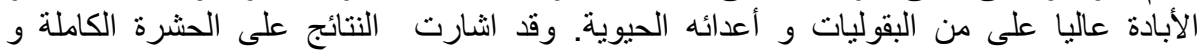

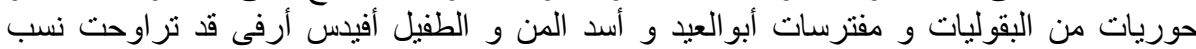
الموت كالآتى بعدها يوم من الرش في العام الأول و الثانى على التى الترتيب. 


\section{J. Agric. Sci. Mansoura Univ., 34 (3): 2155 - 2168, 2009}

Table (5): Average numbers of Aphis crassivora and its parasitoid, Aphidus ervi and predators, Chrysoperla carnea and Conccinella undecimpunctata /leaf on broad bean plants when treated with three different compounds during 2007 season.

\begin{tabular}{|c|c|c|c|c|c|c|c|c|c|c|c|c|c|c|c|c|c|c|c|c|c|}
\hline \multirow{4}{*}{ Treatment } & \multirow{4}{*}{$\begin{array}{l}\text { Rate } \\
\text { /L.W. }\end{array}$} & \multirow{2}{*}{\multicolumn{5}{|c|}{ Pre spraying count }} & \multicolumn{15}{|c|}{ Average number after: } \\
\hline & & & & & & & \multicolumn{5}{|c|}{3 days } & \multicolumn{4}{|c|}{7 days } & \multicolumn{6}{|c|}{15 days } \\
\hline & & \multicolumn{2}{|c|}{ A. crassivora } & \multicolumn{2}{|c|}{ Pr. } & \multirow{2}{*}{ Ap } & \multicolumn{2}{|c|}{ A. crassivora } & \multicolumn{2}{|c|}{$\operatorname{Pr}$} & \multirow{2}{*}{ Ap } & \multicolumn{2}{|c|}{\begin{tabular}{|c|}
$A$. \\
crassivora
\end{tabular}} & \multicolumn{2}{|c|}{$\mathrm{Pr}$} & \multirow{2}{*}{ Ap. } & \multicolumn{2}{|c|}{$\begin{array}{c}A . \\
\text { crassivora }\end{array}$} & \multicolumn{2}{|c|}{$\operatorname{Pr}$} & \multirow{2}{*}{ Ap } \\
\hline & & $\mathbf{A}$ & $\mathbf{N}$ & C & Ch & & A & $\mathbf{N}$ & C & $\mathrm{Ch}$ & & A & $\mathrm{N}$ & $\mathbf{C}$ & $\mathrm{Ch}$ & & A & $\mathrm{N}$ & C & $\mathrm{Ch}$ & \\
\hline Biofly & $1.5 \mathrm{ml}$ & 45.6 & 84.3 & 1.2 & 1.6 & 4.8 & 22.8 & 25.7 & 0.6 & 1.0 & 2.2 & 19.7 & 22.8 & 0.6 & 0.8 & 2.0 & 20.8 & 22.8 & 0.7 & 1.1 & 2.3 \\
\hline Neemex & $1.5 \mathrm{ml}$ & 42.8 & 81.9 & 1.1 & 1.9 & 5.2 & 25.9 & 31.8 & 0.5 & 1.2 & 2.5 & 22.1 & 29.4 & 0.5 & 1.0 & 2.3 & 24.3 & 32.9 & 0.6 & 1.3 & 2.6 \\
\hline Sumithion & $1.5 \mathrm{ml}$ & 40.1 & 79.6 & 1.4 & 1.4 & 6.1 & 3.4 & 5.5 & 0.2 & 0.2 & 0.4 & 2.1 & 4.3 & 0.1 & 0.1 & 0.2 & 1.8 & 3.2 & 0.1 & 0.1 & 0.2 \\
\hline Control & - & 45.7 & 80.6 & 1.5 & 2.0 & 5.9 & 61.8 & 93.1 & 1.6 & 2.6 & 6.5 & 73.8 & 97.9 & 1.8 & 2.9 & 7.6 & 81.2 & 101.8 & 2.0 & 3.2 & 8.1 \\
\hline
\end{tabular}

Table (6): Effect of three different compounds on the average numbers of Aphis crassivora and its and its parasitoid, Aphidus ervi and predators, Chrysoperla carnea and Conccinella undecimpunctata /leaf on broad bean plants during 2007 season.

\begin{tabular}{|c|c|c|c|c|c|c|c|c|c|c|c|c|c|c|c|c|}
\hline \multirow{4}{*}{ Treatment } & \multirow{4}{*}{ Rate /L.W. } & \multicolumn{15}{|c|}{ Percent reduction after: } \\
\hline & & \multicolumn{5}{|c|}{3 days } & \multicolumn{5}{|c|}{7 days } & \multicolumn{5}{|c|}{15 days } \\
\hline & & \multicolumn{2}{|c|}{ A. crassivora } & \multicolumn{2}{|c|}{ Pr } & \multirow{2}{*}{ Ap } & \multicolumn{2}{|c|}{ A. crassivora } & \multicolumn{2}{|c|}{$\operatorname{Pr}$} & \multirow{2}{*}{ Ap } & \multicolumn{2}{|c|}{ A. crassivora } & \multicolumn{2}{|c|}{ Pr } & \multirow{2}{*}{ Ap } \\
\hline & & $\mathbf{A}$ & $\mathbf{N}$ & C & Ch & & $\mathbf{A}$ & $\mathbf{N}$ & $\mathbf{C}$ & Ch & & $\mathbf{A}$ & $\mathbf{N}$ & $\mathbf{C}$ & $\mathbf{C h}$ & \\
\hline Biofly & $1.5 \mathrm{ml}$ & 63.0 & 73.6 & 53.1 & 51.9 & 58.4 & 73.2 & 77.7 & $\overline{58.3}$ & 71.0 & 67.7 & 74.3 & 78.6 & 56.1 & 63.8 & 65.1 \\
\hline Neemex & $1.5 \mathrm{ml}$ & 55.3 & 66.4 & 57.4 & 51.4 & 56.4 & 68.0 & 70.5 & 62.1 & 63.7 & 65.7 & 68.1 & 68.2 & 59.1 & 57.2 & 63.6 \\
\hline Sumithion & $1.5 \mathrm{ml}$ & 93.7 & 94.0 & 86.6 & 89.0 & 92.4 & 96.8 & 95.6 & 94.0 & 96.4 & 97.5 & 97.5 & 96.8 & 94.6 & 96.7 & 97.6 \\
\hline
\end{tabular}


Ragab,M. E. et al.

Table (7): Average numbers of Aphis crassivora and its parasitoid, Aphidus ervi and predators, Chrysoperla carnea and Conccinella undecimpunctata/leaf on broad bean plants when treated with three different compounds during. 2008 season.

\begin{tabular}{|c|c|c|c|c|c|c|c|c|c|c|c|c|c|c|c|c|c|c|c|c|c|}
\hline \multirow{4}{*}{ Treatment } & \multirow{4}{*}{$\begin{array}{l}\text { Rate } \\
\text { /L.W. }\end{array}$} & \multirow{2}{*}{\multicolumn{5}{|c|}{ Pre spraying count }} & \multicolumn{15}{|c|}{ Average number after: } \\
\hline & & & & & & & \multicolumn{5}{|c|}{3 days } & \multicolumn{4}{|c|}{7 days } & \multicolumn{6}{|c|}{15 days } \\
\hline & & \multicolumn{2}{|c|}{$\begin{array}{c}A . \\
\text { crassivora }\end{array}$} & \multicolumn{2}{|c|}{ Pr. } & \multirow[t]{2}{*}{ Ap } & \multicolumn{2}{|c|}{\begin{tabular}{c|} 
A. \\
crassivora
\end{tabular}} & \multicolumn{2}{|c|}{$\operatorname{Pr}$} & \multirow[t]{2}{*}{ Ap } & \multicolumn{2}{|c|}{$\begin{array}{c}A . \\
\text { crassivora }\end{array}$} & \multicolumn{2}{|c|}{$\operatorname{Pr}$} & \multirow[t]{2}{*}{ Ap } & \multicolumn{2}{|c|}{$\begin{array}{c}A . \\
\text { crassivora }\end{array}$} & \multicolumn{2}{|c|}{$\operatorname{Pr}$} & \multirow[t]{2}{*}{ Ap } \\
\hline & & A & $\mathbf{N}$ & C & Ch & & A & $\mathbf{N}$ & $\mathbf{C}$ & $\mathbf{C h}$ & & A & $\mathbf{N}$ & C & Ch & & A & $\mathbf{N}$ & C & Ch & \\
\hline Biofly & $1.5 \mathrm{ml}$ & 39.1 & 79.2 & 1.3 & 1.9 & 5.7 & 15.1 & 20.7 & 0.7 & 1.0 & 2.9 & 11.2 & 19.4 & 0.7 & 0.9 & 2.4 & 11.6 & 18.4 & 0.8 & 0.9 & 2.7 \\
\hline Neemex & $1.5 \mathrm{ml}$ & 38.7 & 77.4 & 1.2 & 1.6 & 6.2 & 18.9 & 28.1 & 0.6 & 0.9 & 3.7 & 13.6 & 25.4 & 0.6 & 0.8 & 3.1 & 14.9 & 26.3 & 0.7 & 1.0 & 3.5 \\
\hline Sumithion & $1.5 \mathrm{ml}$ & 35.9 & 75.1 & 1.6 & 1.5 & 5.3 & 2.8 & 4.2 & 0.2 & 0.2 & 0.5 & 1.6 & 3.1 & 0.1 & 0.1 & 0.3 & \begin{tabular}{|l|}
1.2 \\
\end{tabular} & 2.9 & 0.1 & 0.1 & 0.1 \\
\hline Control & - & 40.5 & 78.5 & 1.7 & 1.8 & 6.1 & 43.9 & 83.1 & 1.9 & 2.1 & 7.3 & 47.1 & 86.5 & 2.2 & 2.4 & 8.1 & 49.7 & 89.6 & 2.5 & 4.7 & 8.7 \\
\hline
\end{tabular}

Table (8): Effect of three different compounds on the average numbers of Aphis crassivora and its and its parasitoid, Aphidus ervi and predators, Chrysoperla carnea and Conccinella undecimpunctata/leaf on broad bean plants during. 2008 season.

\begin{tabular}{|c|c|c|c|c|c|c|c|c|c|c|c|c|c|c|c|c|}
\hline \multirow{4}{*}{ Treatment } & \multirow{4}{*}{$\begin{array}{l}\text { Rate } \\
\text { /L.W. }\end{array}$} & \multicolumn{15}{|c|}{ Percent reduction after: } \\
\hline & & \multicolumn{5}{|c|}{3 days } & \multicolumn{5}{|c|}{7 days } & \multicolumn{5}{|c|}{15 days } \\
\hline & & \multicolumn{2}{|c|}{$\begin{array}{c}\text { A. } \\
\text { crassivora }\end{array}$} & \multicolumn{2}{|c|}{$\operatorname{Pr}$} & \multirow[t]{2}{*}{ Ap } & \multicolumn{2}{|c|}{$\begin{array}{c}A . \\
\text { crassivora }\end{array}$} & \multicolumn{2}{|c|}{$\mathrm{Pr}$} & \multirow{2}{*}{ Ap } & \multicolumn{2}{|c|}{ A. crassivora } & \multicolumn{2}{|c|}{$\mathrm{Pr}$} & \multirow{2}{*}{ Ap } \\
\hline & & A & $\mathbf{N}$ & C & Ch & & A & $\mathbf{N}$ & C & Ch & & A & $\mathbf{N}$ & C & Ch & \\
\hline Biofly & $1.5 \mathrm{ml}$ & 64.4 & 75.3 & 51.8 & 54.9 & 57.5 & 75.4 & 77.8 & 58.4 & 64.5 & 68.3 & 75.8 & 79.6 & 58.2 & 68.4 & 66.8 \\
\hline Neemex & $1.5 \mathrm{ml}$ & 54.9 & 65.7 & 55.3 & 51.8 & 50.1 & 69.8 & 70.2 & 61.4 & 62.5 & 62.3 & 68.6 & 70.2 & 60.3 & 58.3 & 60.4 \\
\hline Sumithion & $1.5 \mathrm{ml}$ & 92.8 & 94.7 & 88.8 & 88.6 & 92.1 & 96.2 & 96.3 & 95.2 & 95.0 & 95.7 & 97.3 & 96.6 & 95.8 & 95.6 & 98.7 \\
\hline
\end{tabular}


J. Agric. Sci. Mansoura Univ., 34 (3), March, 2009 